\title{
Student Perceptions of Their Interactions with Peers at a Cyber Charter High School
}

\author{
Jered Borup, Shea Walters and Meagan Call-Cummings \\ George Mason University
}

\begin{abstract}
K-12 online students are increasingly communicating and collaborating with their peers; however, research on the topic is limited-especially research examining students' perceptions and experiences. Guided by the Adolescent Community of Engagement framework's concept of peer engagement, this qualitative descriptive case study examined learner-learner interactions at a cyber charter high school. Ten students were selected by teachers based on their ability to independently engage in learning activities - five students were more independent and five required more support from others. Each student took part in two, hour-long interviews for a total of 20 interviews. The interviewers covered students' perceptions and experiences regarding teachers, parents, and peers. This report only focuses on peers. Iterative emic coding and thematic analysis revealed that their interactions with peers allowed them to develop friendships, improve their motivation, receive peer instruction, and collaborate effectively with others. Challenges are also covered. The article concludes with recommendations for research and practice.
\end{abstract}

Keywords: learner-learner interaction, online communication, online collaboration, K-12 online learning, cyber charter school

Borup, J., Walters, S., \& Call-Cummings, M. (2020). Student perceptions of their interactions with peers at a cyber charter high school. Online Learning, 24(2), 207-224. https://doi.org/10.24059/olj.v24i2.2015

\section{Student Perceptions of Their Interactions with Peers at a Cyber Charter High School}

High school students are increasingly enrolling in online courses (Digital Learning Collaborative, 2019; Gemin \& Pape, 2017). While the majority of online students only take online courses to supplement their in-person coursework, enrollments at full-time online programs, commonly called cyber schools, are quickly growing making it especially important to examine the learning strategies used in these schools (Gemin \& Pape, 2017).

A national survey of 100 cyber charter high schools found that $60 \%$ frequently relied on independent study models and $40 \%$ rarely or never employed "collaborative learning involving two of more students working together" (Gill et al., 2015, p. 51). While lacking in many cyber charter schools, learner-learner interactions are seen as a critical component to meaningful 
educational experiences because they allow students to co-construct understanding of the course material (Garrison, Anderson, \& Archer, 2000). Furthermore, there has been an increased focus on leveraging learner-learner interactions in ways that allow students to develop twenty-first century skills such as communication, collaboration, creativity, and critical thinking-commonly referred to as the 4Cs (National Education Association, n.d.). As a result, it is especially important for students in cyber schools to have quality learner-learner interactions because, unlike students who are enrolled in supplemental online courses, cyber charter students do not have the opportunity to develop the 4Cs in in-person environments.

Little research exists that examines learner-learner interaction in cyber high schoolsespecially from the students' perspective. As the primary stakeholder within any educational context, students provide important insights that can help increase and improve learner-learner interactions in cyber charter schools. In this study we interviewed 10 students at a cyber charter high school that attempted to facilitate high levels of learner-learner interactions. The student interviews addressed the following question: What are students' perceived advantages and disadvantages of their interactions with other students at a cyber charter high school?

\section{Review of Relevant Literature}

\section{Frameworks}

Anderson (2009) explained that learner-learner interactions in distance education settings are dependent on available communication technologies. Prior to the internet, learner-learner interactions were limited, and courses instead focused on learners' interactions with the content and instructors (Garrison, 2009). Moore (1989) was one of the first to draw researchers' attention to learner-learner interactions by explaining that "learner-learner interaction among members of a class or other group is sometimes an extremely valuable resource for learning, and is sometimes even essential" (p. 4) because it helps students develop communication skills and can have a stimulating and motivating effect - especially for younger learners. At the time, Moore admitted that the field knew little of the potential of learner-learner interactions to transform students' learning and predicted that this potential would "be a challenge to our thinking and practice" (p. 4).

To describe a more collaborative constructivist approach to learning online, Garrison et al. (2000) developed the Community of Inquiry (CoI) framework. The framework identified and defined the following three presences:

- Cognitive presence: "the extent to which the participants in any particular configuration of a community of inquiry are able to construct meaning through sustained communication" (Garrison et al., 2000, p. 89).

- Social presence: "the ability of participants in the Community of Inquiry to project their personal characteristics into the community, thereby presenting themselves to the other participants as "real people"' (Garrison et al., 2000, p. 89).

- Teaching presence: "the design, facilitation, and direction of cognitive and social processes for the purpose of realizing personally meaningful and educationally worthwhile learning outcomes" (Anderson, Rourke, Garrison, \& Archer, 2001, p. 5). 
The biggest contribution of the framework was illustrating the interconnections of the different presences. For instance, while social presence was not a new concept (see Short, Williams, \& Christie, 1976), the CoI framework moved the field's understanding forward by explaining that social presence supports the development of cognitive presence because it allows participants to more freely exchange ideas in ways that allow them to co-construct their understanding of the course content.

It is important to note that Garrison and his colleagues (Anderson, Rourke, Garrison, \& Archer, 2001; Garrison, Anderson, \& Archer, 2001; Rourke, Anderson, Garrison, \& Archer, 2001) identified the indicators of cognitive, social, and teaching presences by analyzing discussion board comments. As a result, CoI does not describe the presences in other types of activities. Archer (2010), one of the original authors of the CoI framework, challenged researchers to move beyond discussion boards to other aspects of the course. Archer recognized that "this attempt to broaden the scope of the CoI framework entails a new look at the overall rationale for the framework" (p. 69). The framework also needs to be reexamined for K-12 online learning due to differences in the context and students.

To better describe the K-12 online learning environment, Borup, West, Graham, and Davies (2014) developed the Adolescent Community of Engagement (ACE) framework, which identified four types of engagement: teacher engagement, parent engagement, peer engagement, and student engagement. Student engagement was the target variable and the other three types of engagement were viewed as supports. Teacher engagement and parent engagement are beyond the scope of this article. The remainder of this section will focus on peer engagement.

The ACE framework identified the following three indicators of peer engagement:

- Instructing: occurs when students share previously obtained content knowledge or learning strategies with other students.

- Collaborating: occurs when students engage in sustained communication to co-construct an understanding of the course material and/or collaborate to complete tasks.

- Motivating: occurs when students intentionally or unintentionally encourage or stimulate others to engage more fully in learning activities.

The ACE framework also viewed social presence as an "enabling variable" (p. 21) because students are more likely to impact others' engagement once they have established their social presence and "a sense of closeness has been formed" (Borup, West, Graham, \& Davies, 2014, p. 21). Of the types of engagement identified in the ACE framework, peer engagement is the most under-researched and only one research study has used the framework to examine learner-learner interactions at a cyber charter school. Furthermore, that previous study only examined teachers' perceptions and we intend on adding additional insights by examining students' perceptions. While case studies are not intended to test a framework, they can be helpful in expanding and refining definitions and indicators (Merriam, 1998).

\section{Learner-Learner Research}

While the frameworks described above argue the importance of learner-learner interaction, empirical research on the topic of K-12 online courses is lacking (Lin, Zheng, \& Zhang, 2017). Zhang, Liu, and Lin (2018) explained that learner-learner interaction in online courses "generally takes place through online discussions" (p. 278) but other types of collaborative learning also 
occur. For instance, a national survey of cyber charter schools found that $21 \%$ of high schools frequently used "collaborative learning involving two or more students working together" (Gill et al., 2015. p. xiv). Some cyber charter schools also foster a sense of community among students by providing students opportunities for social or academic in-person activities, "such as (but not limited to): field trips, study sessions, additional orientation/training assistance, open houses, conferences, end-of-year celebrations" (Watson, Murin, Vashaw, Gemin, \& Rapp, 2010, p. 87).

Gill et al.'s (2015) national survey research found that $60 \%$ of cyber charter high schools largely relied on an independent study model with little or no learner-learner interactions. There is also some indication that online students experience less learner-learner interactions than their peers taking in-person courses. Carver and Koloski (2015) compared the perceptions of 41 online high school students with those of 543 in-person students enrolled in a career and technical education course. They found that online students reported significantly less learner-learner interactions and collaboration than did in-person students. The authors concluded that online course designers and teachers need to be more deliberate in promoting and facilitating learnerlearner interactions and collaboration.

In a larger study, Oliver, Osborn, and Brady (2009) surveyed 1,648 students enrolled in online courses offered by North Carolina Virtual Public School. While the majority of the survey used Likert scales to assess students' expectations for their teachers, students also had the opportunity to type in comments regarding other aspects of their online learning. Following the qualitative analysis of students' statements, Oliver et al. (2009) recommended that online courses provide students with more learner-learner interactions in response to "the numerous comments by NCVPS students who expected their teachers to incorporate more collaborative activities with their peers" (p. 39).

The amount and types of learner-learner interactions also vary across online programs and across individual students within the program. For instance, student survey research that included 77 participants at a cyber charter high school found that the student respondents reported spending an average of 91 minutes per week engaging in learner-learner interactions (Borup, Graham, \& Davies, 2013). However, student responses had a standard deviation of 125 minutes and 17 students reported no learner-learner interactions. The large majority of the students also perceived that their learner-learner interactions were valuable to their learning $(83 \%)$ and motivational $(81 \%)$. It was also found that the amount of time students spent engaging in learner-learner interactions was significantly correlated with students' satisfaction and end-of-semester grade whereas neither of the other interactions (i.e., learner-parent and learner-content) were significantly correlated with those course outcomes. Similarly, Lin et al. (2017) conducted a regression analysis on 466 completed surveys from high school students who enrolled in online world language courses to supplement their in-person course work. While students' interactions with the content and their teacher appeared to have an impact on their satisfaction, their interactions with other students were found to have no significant impact when controlling for student demographics and learning strategies. Furthermore, only learner-content interactions impacted students' perceived progress in the course. While the findings from these two studies appear contradictory, it is important to note that they were conducted in different settings and it is possible that learner-learner interactions are more valuable in full-time online schools as compared to supplemental online programs.

Beldarrain's (2008) dissertation research is especially important because it examined the actual learner-learner interactions for 30 online students including their emails, discussion board 
comments, and instant messages. They found a significant relationship between the frequency that students interacted with other students and student achievement. Students were also surveyed regarding their preferences and perceptions. The large majority of students $(73.9 \%)$ reported that they felt comfortable communicating with peers online. The majority of students $(60.9 \%)$ believed that communicating with other students helped them to succeed in the course and $69.6 \%$ reported that they would communicate more with peers regarding course assignments if given the opportunity.

Learner-learner interactions have also been highlighted as a way to lessen students' isolation by developing a sense of social presence. Garret Dikkers, Whiteside, and Lewis (2013) conducted student and teacher surveys followed by interviews and focus groups with teachers. The majority of surveyed students and teachers agreed that the five measured aspects of social presence were either important or very important. While students largely agreed that class cohesion and community were important, many students also discussed "how little community they sense in their online environment" (p. 162). Teachers also noted some students' unwillingness to engage with peers. Some students also shared that they only interacted with peers during discussion board activities. While learner-learner interactions appeared limited, students noted the interactions with peers could help them on assignments, stay motived, maintain interest in the course, and progress through the course.

Borup (2016) examined teachers' perceptions at a cyber charter school with relatively high levels of learner-learner interactions and found that teachers valued learner-learner interactions because they provided students with important friendships and motivated students to engage in learning activities. The teachers also shared examples of how students collaborated together on projects and how more knowledgeable students tutored other students. However, teachers also found that not all learner-learner interactions were beneficial and shared examples of cheating and bullying. While student and teacher surveys and interviews with teachers have helped us to better understand learner-learner interactions in online courses, more research is needed that provides rich descriptions of students' perceptions of their interactions with other students.

\section{Methods}

This article forms part of a larger research agenda at the cyber charter school that has focused on expanding and refining the elements identified in the ACE framework. Articles sharing the findings describing students' perceptions of teacher engagement and parent engagement have been previously published. This qualitative descriptive case study focuses on students' perceptions of and experiences with peer engagement.

\section{Research Setting}

The school was selected because it offered students several opportunities to interact with peers. For instance, in our previous research (see Borup, 2016) we found that the school held optional monthly academic and social in-person activities throughout the state. Students were also encouraged to communicate via social media platforms for academic and social purposes. Within the online course teachers frequently required students to participate in online discussion activities. However, they tended to make student collaboration on course projects optional to provide student flexibility. Similarly, the courses had weekly deadlines but students were provided with an extra week where they could turn in assignment without penalty. Courses were delivered 
asynchronously with only optional synchronous study sessions. Teachers also held weekly office hours where students could receive synchronous support. Furthermore, the school's Honor Society created and facilitated a peer mentoring program. Lastly, each teacher was assigned to 20 students and tasked with "shepherding" them by developing relationships with the student, monitoring their progress, and facilitating support when needed.

\section{Participants and Data Collection}

We believed that students' experiences were likely different based on the course subject so we sampled a teacher in each of the core subjects (i.e., language arts, social studies, math, and science) and one of the elective teachers. The teachers were also sampled because they were identified as particularly active shepherds following focus groups that we conducted for another research project. Each of the five teachers, then identified potential student interview participants. The potential participants were students that the teachers had shepherded the previous semester. This helped to ensure that the teacher was familiar with the students' performance, tendencies, and needs.

Specifically, we asked each of the five teachers to recommend a student who was highly dependent on their shepherding support and a student who was able to engage in their coursework more independently. Of the 10 sampled students, six were male, four were seniors, two were juniors, three were sophomores, and one was a freshman. Each of the 10 students then participated in two one-hour interviews for a total of 20 interviews. The semi-structured interview protocol focused on the elements identified in each of the three types of engagement-peer, teacher, and parent engagements - but this research only focuses on student comments regarding peer engagement. Specifically the interviewer started by asking students more general questions regarding their perceived importance of peers and how frequently they interacted with other students. Students then shared the subjects and purposes of their interactions with peers. Following, students were asked if they were able to develop friendships with others, how those friendships were developed, and what obstacles they encountered when forming friendships. Students were then asked to list the ways that other students could benefit their learning experience. Each response was then discussed further, and students were asked to elaborate on the type of peer engagement and share any experiences they had regarding it. Finally, the interviewer asked students regarding any indicator of peer engagement that had not been discussed earlier but identified in the ACE framework. For accuracy, the interviews were transcribed and sent to the students for review prior to analysis.

\section{Data Analysis}

Because we were interested in how our data might inform the ACE framework, we decided to approach this data in a completely emic way; that is, we did not let preexisting theories, including the ACE framework, dictate how we coded the data. First, one of the authors went through the entire set of data and coded for emergent themes, following Carspecken's (1996) approach. She began by becoming very familiar with the data, reading through all the interview transcripts multiple times, and conducting what Carspecken refers to as low-level coding, "which is coding that falls close to the primary record and requires little abstraction" (p. 146) from a participant's words or actions. Upon completion of this process, the coder submitted her list of "raw codes" (p. 150) to the other two authors separately for peer debriefing to check inference levels and to start to organize the codes into potential broader categories and themes. Each of the peer debriefings were first conducted separately followed by a combined meeting with all three 
authors to discuss any questions we had about the low-level coding as well as to make suggestions for ways in which the codes might take on added levels of abstraction. Carspecken notes that this iterative process of collaborative coding and peer debriefing is useful and adds to the validity of the data analysis and subsequent findings. Upon completion of this process, the original coder engaged in high-level coding, requiring a greater degree of abstraction from the actual words of the participants. This high-level coding was conducted only on select passages of interview data that were chosen for this more intensive analysis. These passages were selected by all three authors because of their potential to offer additional nuances to the ACE framework.

\section{Results}

While students shared various benefits of engaging with their peers (see Table 1), they also disclosed drawbacks and obstacles (see Table 2). While the identified advantages were not purposefully aligned with the ACE framework, as the analysis was synthesized there was a strong link between the themes identified in this data and those within the ACE framework, including instructing, befriending, collaborating, and motivating. The following sections will discuss each theme. Pseudonyms were used when quoting students to protect their identity.

Table 1

Themes Highlighting Students' Perceived Benefits

\begin{tabular}{|c|c|c|c|}
\hline Benefits & $\begin{array}{c}\text { \# of } \\
\text { Students }\end{array}$ & $\begin{array}{c}\text { \# of } \\
\text { References }\end{array}$ & Example Quote \\
\hline Instructing & 9 & 36 & $\begin{array}{l}\text { "Peers are very important...in your class. I } \\
\text { relied on a lot of them too." }\end{array}$ \\
\hline Befriending & 7 & 23 & $\begin{array}{l}\text { "It was something that I looked forward to } \\
\text { everyday-getting online and knowing that I } \\
\text { could talk to them." }\end{array}$ \\
\hline Collaborating & 7 & 15 & $\begin{array}{l}\text { "You get to share your opinions and ideas with } \\
\text { each other and you get a lot of perspective } \\
\text { concerning the topic and then it just sticks." }\end{array}$ \\
\hline Motivating & 6 & 29 & $\begin{array}{l}\text { "When they would come to me and ask if I } \\
\text { could help them with an assignment, it made } \\
\text { me want to do well on the assignment." }\end{array}$ \\
\hline
\end{tabular}


Table 2

Themes Highlighting Students' Perceived Drawbacks

\begin{tabular}{|c|c|c|c|}
\hline Drawbacks & $\begin{array}{c}\text { \# of } \\
\text { Students }\end{array}$ & $\begin{array}{c}\text { \# of } \\
\text { References }\end{array}$ & Example Quote \\
\hline $\begin{array}{l}\text { Distracting or } \\
\text { discouraging }\end{array}$ & 7 & 12 & $\begin{array}{l}\text { "Sometimes if people G-chat me while I'm } \\
\text { working on something, sometimes it is really } \\
\text { kind of a bother to have to go G-chat them } \\
\text { back." }\end{array}$ \\
\hline $\begin{array}{l}\text { Communicating } \\
\text { was difficult }\end{array}$ & 4 & 9 & $\begin{array}{l}\text { "I was kind of really shy and so I got } \\
\text { embarrassed working with other peers because I } \\
\text { didn't know who to be online." }\end{array}$ \\
\hline $\begin{array}{l}\text { Collaborating } \\
\text { was a negative } \\
\text { experience }\end{array}$ & 4 & 8 & $\begin{array}{l}\text { "We didn't get his part of the project until the } \\
\text { very, very last minute and we barely had } \\
\text { enough time to put it in the SlideRocket and } \\
\text { even when it was there, it wasn't that good." }\end{array}$ \\
\hline Bullying & 2 & 9 & $\begin{array}{l}\text { "[They] had taken-some of my pictures from } \\
\text { either the school website or my personal } \\
\text { Facebook which I had assumed I'd made } \\
\text { private, so I don't know how they got them-- } \\
\text { and were just drawing rude things on my face." }\end{array}$ \\
\hline
\end{tabular}

\section{Instructing}

One of the major themes identified is that students provided each other with instructional support in ways that helped them learn the material and complete learning activities. Several students, like Amy, "would ask others [peers] how to do things before going to [their] teachers." We found three reasons why students turned to peers before their teachers. First, and most commonly, students believed their teachers were too busy to help - especially when it was outside of their office hours. As Amy stated, "teachers were there for students, of course, but sometimes they're busy." Second, Everly pointed out that she was more comfortable communicating with other students than her teachers making it "easier to come to a friend to ask for help." Third, Fiona added that she turned to her peers rather than her teacher so that she would appear to her teacher to be more of an original thinker and independent learner: "If I were going to the same teacher that was grading an assignment, my work wouldn't seem as original because they helped me with it."

Much of the peer instruction occurred as part of a peer mentoring program that was established by the school's Honor Society. Eamon described this program as "a class that's set up for students who are more experienced with [online learning]. It allows them to help kids and reach out to kids that aren't doing so well or need a friend." Students who excelled in the online environment and earned strong grades were identified by teachers and asked to join the peer mentor program to assist other students. When students had subject dependent questions, they would reach out to the peer mentor who was designated to that subject area. Karl, who "turned to peer mentors 
multiple times," found that the mentorship program was beneficial to him, especially when they assisted him with the uncertainties he had-mostly with math.

Some of the methods peer mentors used to assist others included showing the steps of solving a problem, providing examples, reviewing work, and sharing learning strategies. Students shared their experiences of how peers approached them for instructional support. Everly, a peer mentor, said, "They would ask me for help, but they don't ask me straight for the answers," which would have been considered cheating. Amber described her role as a peer mentor as one that was filled with many students reaching out to her for help throughout the school year. According to Amber, this help included technical assistance with the online structure as well as subject-specific content. Students also tended to use more synchronous modes of communication such as instant messaging so they would receive or provide help quickly. Often when students needed to demonstrate something such as solving math equations, they shared their screen so they could show the required steps.

\section{Motivating}

Peer-to-peer motivation was illustrated in two ways - students explicitly encouraging one another and students wanting to present themselves in certain ways to their peers. Students appeared to appreciate it when their peers provided encouraging support when they lacked confidence or the desire to work in classes that were "not as fun as other classes." Avery described how she and her friends always gave "each other pep talks saying, 'You know, you just need to believe in yourself. You can do this, you just don't have the confidence right now." Avery also spoke of how her peers supported each other by cheering one another on through the use of "mock cheerleading routines" by shouting "You can do it!" while waving "pompoms." Amy said that when she was "really stressed on assignments" her friends checked in on her using G-chat to see how her work was going and to keep her calm.

Students reported that to appear intelligent and competent to their peers, they were motivated to put out more effort and do better on class assignments. Similarly, some students were competitive and wanted to do better than their peers. Amy stated, "I basically want my work to stand out compared to my peers" and described her desire to prove to others, in addition to herself, that she was capable of achieving great things. Eamon explained that the visibility of a students' individual class rank in the learning management system motivated him: "I found out that when I login where it shows my grades down below, it says the class rank.... It was my determination to be number one." He also described feeling encouraged when people gave him compliments on his ideas in discussion forums and on projects he completed. When students came to Fiona for help it motivated her to do well on the assignment. She explained, "If it was something like an essay question and they asked if they could read what I wrote for the questions, I would quickly change a few things to make it better and make me seem smarter" and "if I knew that someone besides the teacher and myself would be looking at an assignment, it made me want to do my best and impress not just my teachers, but my peers as well."

\section{Collaborating}

Students tended to have positive views of collaborative projects as illustrated by Avery when she stated, "not only is your own workload slightly lessened, but you get to share your opinions and ideas with each other and you get a lot of perspective concerning the topic and then it just sticks." Fiona mirrored this positive outlook: "I really liked it because I liked working with people, whether it [was] my friends or new people. I think group projects are really important." 
Karl described the communication that took place during group work as key because "commenting on what each other is doing helps us more to engage in what we're doing and to comment and to help each other on what part we decided to work on." Mitchell discussed how he and a friend went to each other's homes to sit side-by-side working on different projects but occasionally would collaborate together to complete the same project.

While students were generally open to the idea of collaboration on projects, in practice they found it could be a frustrating process because some of their peers were not good collaborators. Students spoke of times when they worked with peers who did not complete their work until the very end of the deadline and thus left the rest of the group minimal time to complete the project. Avery added,

There are some kids that procrastinate and some that don't, or some that accept a lower grade and some that don't really want to. I think it makes it harder because in the end you're scrambling to finish the project because either your partner's not doing it or you're procrastinating.

Mitchell also did not like collaborative projects because of the inconvenience of contacting other students. These drawbacks led to students opting out of group work when given the opportunity.

Discussion boards were also another form of collaboration. Teachers would post questions or ask students to respond to prompts and students were required to post a response and respond to at least two of their peers. Despite this being a common practice, only two students referred to discussion questions in their interviews. Both students identified the potential for learning but found that they were largely ineffective at their school. Mitchell described them as "timeconsuming and pointless." He recognized the benefit of discussing content specific things and sharing opinions, but he felt that all his classes used "literally the same question every time," which in turn, made it "pointless." Eamon similarly found that while the discussion boards could be motivational they tended to lack value because his peers were only posting because it was "assignment-based" and there was "not a lot of depth" in the discussion threads.

\section{Befriending}

The interviewed students valued making friends in the online environment. In fact, these relationships appeared to make the other types of student engagement more effective. However, forming relationships was a task that for some proved difficult to do outside of the in-person classroom setting. Fiona stated that making friends was really important to her and that it was something she "looked forward to everyday - getting online and knowing that I could talk to [friends]...it was a big part of the schooling experience." Amy said that making friends online was something that was outside of what she was used to. She explained, "we would chat not knowing what you looked like. It was really nice, but it was different."

Students were also required to attend a start-of-the-year orientation. Then during the academic year, the school would put together optional in-person functions that were academic and social. Charity described that the school "sets up a time and a place to meet where you can kind of get to know the students." Charity enjoyed these times because she liked being with friends and talking to people: "It was just fun to get to know students and classmates better than I would know just by talking to them online." Eamon added that the in-person events actually improved his online interactions with those he connected with in-person. Some students who wanted to attend in-person events found it difficult to do so due to distance and demanding schedules. Everly explained, "I 
wish that I could just hang out with a couple more of them, but we're spread throughout the whole state."

Not all students had positive experiences making friends online. Everly described herself as "not having many friends" and admitted, "I wish sometimes that I had more interaction [with peers]." However, she said she had increased her efforts and was "getting to know [her peers] better." While Avery was successful at making friends, she also acknowledged that at times her friendships proved distracting. She spoke of excessive chatting and interactions with friends through social media. She said if she "would see something funny" she would feel obliged to "screenshot" and send it to her friends, which was a "real distraction." Eamon agreed that the two biggest distractions for him were chatting with friends and social media. Furthermore, Fiona spoke of times when she befriended people who were not the "best" because they actively distracted her from her work.

While communicating and interacting with friends was identified by some students to be a distraction, other students spoke to the fact that communicating with people they did not know was very difficult. Everly described herself as really shy and found that she was "embarrassed working with other peers" because she was unsure how to act online. She expanded on this notion by describing her difficulty with acknowledging that when she interacted with others online there was someone on the other end who was going to be "listening" to what she had to say. Conversely, Eamon was not worried about reaching out to other students; however, he found that even after emailing peers multiple times only a few ever responded. The lack of responses could be due to the fact that students like Mitchell was not interested in communicating with other students online. He stated, “it's not like I don't know them...I don't want to know them." He wanted to focus his time on getting "stuff done." He also described communicating with others online as being awkward and that he doesn't like "straightforward contact."

One final negative perspective was bullying. Bullying was not common but did occur. Eamon commented that he had heard of bullying occurring at the school at one point but that it had been resolved. Only Avery shared a direct experience that she had with bullying. It has started when she and a boy were frequently communicating on Skype. According to Avery, she decided she no longer wanted to interact with him and he responded by "screaming and cussing" at her. He then turned "all her best friends" against her and continued this behavior for "over a year." The bullying progressed to an "anti-Avery" Facebook page where they posted demeaning messages. For help Avery turned to two other students who became "absolutely livid." Her friends informed the school administrators and "reported the Facebook group to Facebook and they deleted it."

\section{Discussion and Conclusion}

In this research we examined students' perceptions and experiences at a single cyber charter school. In other words, our goal was to understand "how things work" at a single school (Stake, 2010, p. 14). While the "complex specificness" (Wolcott, 1994, p. 107) prevents generalizations, the rich descriptions provided in our findings can provide important clarity to this under-researched topic and offer theoretical insights. We appreciate Merriam and Tisdell's (2009) argument, based on Lincoln and Guba's (1985) landmark contribution, that transferability is an appropriate and useful goal for a single case study; therefore, we offer these findings as "extrapolations [or] modest speculations on the likely applicability of findings to other situations under similar, but not identical, conditions" (Patton, 2002, p. 584). The findings from this study 
highlighted several benefits of learner-learner interactions at the cyber charter school. Specifically, the majority of students believed that interactions with their peers were beneficial because their peers could engage in instructing, befriending, collaborating, and motivating support. This supports the indicators originally identified in ACE framework (i.e,. instructing, collaborating, and motivating) as well as befriending that was identified in Borup's (2016) follow-up research examining online teachers' perceptions of peer engagement. Interestingly, the ACE and CoI frameworks have focused on the need to establish social presence rather than forming close friendships. Befriending moves beyond the concept of social presence or participants' ability to simply "project their personal characteristics" into mediated communication (Garrison et al., 2000, p. 89). Similar to Garrison et al.'s (2000) claim that students' social presence was foundational to students' cognitive presence, students' ability to form relationships and friendships with other students appeared to improve students' other support efforts. While a strong sense of social presence can be developed using asynchronous text (Rouke et al., 2001), students in this research found that friendships were best formed in synchronous communication. Specifically, in-person events appeared to be especially helpful when developing relationships. It is also important to note that not all students had the opportunity to attend these events which could leave them feeling isolated. When providing in-person events schools should work to make them as inclusive as possible or they run the risk of actually forming close school communities with some students while others are left outside looking in. However, those students who cannot attend in-person events may find online synchronous communication helpful at forming friendships. Similar to Velasquez, Graham, and West (2013), we found that K-12 online students tend to prefer communicating using text instant messaging. Some students also communicated via video, including screensharing programs. The use of asynchronous and synchronous video communication appears especially helpful and efficient in developing a sense of closeness in higher education (Borup, West, Thomas, \& Graham, 2014; Thomas, West, \& Borup, 2017), and may have similar results in K-12 online courses. More research is needed that explores how students form relationships with peers both online and in-person.

The schools' peer-mentoring program appeared successful at providing students with instructional support at times when the teacher was unavailable. There was also some indication that in some cases students felt more comfortable contacting a peer as compared to their teacher. Research on peer tutoring programs has focused largely on literacy and math (Zeneli, Thurston, \& Roseth, 2016), the two subjects that students in this research also appeared to benefit most from the program. Research examining how peer tutoring programs impact learning outcomes have been mixed but a meta-analysis of 41 articles found that programs are likely to be the most beneficial at the elementary school level as compared to high school (Zeneli et al., 2016). This may be due to the complexity of the high school curriculum - especially in subjects such as math. As a result, online high schools looking to implement peer tutoring programs should not become overreliant on them and also provide other tutoring options with content experts. Researchers can also help schools to better understand the impact that peer tutoring programs have on student learning.

Students were generally positive regarding their interactions with peers. However, they did highlight some drawbacks and obstacles. While bullying was uncommon, one student shared a direct experience when she was being bullied online for a prolonged period of time. There is some indication that bullying occurs less frequently in online courses as compared to in-person courses (Harvey, Greer, Basham, and Hu, 2014). Rice (2012) added that online learning "puts everybody on equal footing" (p. 154) because communication commonly lacks visual cues. However, when bullying does occur in online courses it can be especially harmful considering students frequently 
turn to online learning to avoid bullying at brick-and-mortar schools (Beck, Maranto, \& Lo, 2013). Bullying also appears to be more common with students with disabilities as compared to general education students (Beck, Egalite, \& Maranto, 2014). Teachers have shared that they believe "students unintentionally bullied their peers" (Borup, 2016, p. 242) because they do not fully understand how to communicate online or how peers receive their communications. As a result, harmful interactions between peers could be avoided if schools taught their students to follow netiquette so that they communicate in open and accepting ways that avoid misconceptions. At the same time online teachers may not be receiving adequate professional development regarding cyberbulling and other related issues (see Dawley, Rice, \& Hinck, 2010). While bullying did not appear to be common in this research, online programs should still use preventative measures so that bullying does not become a bigger issue - especially as online programs move to more collaborative forms of learning. We also agree with previous calls (Harvey et al., 2014; Tysinger, Tysinger, \& Diamanduros, 2018) that more research is needed that examines existing anti-bullying programs and policies in online courses.

Despite how common they were in online courses, only two students volunteered their perceptions regarding discussion board activities. Both students identified the potential for having discussion activities, however both felt that the discussions tended to lack "depth" or were "timeconsuming and pointless." We recommend more targeted research on student perceptions of and experiences with discussion boards. We also recommend that researchers analyze actual discussion board comments similar to previous research in higher education (Anderson et al., 2001; Garrison et al., 2001; Rourke et al., 2001).

While students generally believed that collaboration on projects could be helpful, they tended to avoid them because in practice they were difficult to arrange and could be frustrating when students' goals and efforts were not aligned. This is clearly not a challenge unique to online learning but it may be more difficult to overcome in asynchronous learning environments. While it would remove some of students' learning flexibility, more effective collaboration may be more easily facilitated in synchronous environments.

Currently there exists a tension between providing students with a highly flexible learning environment while also providing them with a collaborative and interaction rich learning experience (Garrison, 2009). Flexibility is likely more important in supplemental programs that enroll students across many school districts, each with slightly different academic calendars. Supplemental online students can also vary greatly in when they work on their courses due to their in-person class schedules. These factors make it difficult to have common assignment start and end dates that make collaboration and discussion easier. However, meaningful collaboration is also lacking in many full-time cyber charter schools where students share the same academic calendar and learning during similar times of day (Gill et al., 2015). It could also be argued that collaboration is especially important in cyber high schools because students are taking all or most of their courses online making it feasible that some students are graduating having never formally collaborated with their peers on school projects. As a result, additional research is needed that specifically focuses of effective collaboration strategies that find a balance between flexibility and structure.

Garrett Dikkers (2018) explained that discussion and collaboration tools are now in place, but we lack quality research that highlights how to use them well to create discussion- and collaboration-rich environments that strengthen student engagement and learning outcomes. This will require researchers to develop a more coordinated research agenda that works closely with 
practitioners and students. This will also require that researchers use common terminology and frameworks. Graham, Henrie, and Gibbons (2014) stated, "Well-established scholarly domains have common terminology and widely accepted models and theories that guide inquiry and practice, while researchers in less mature domains struggle to define terms and establish relevant models" (p. 13). Based on these criteria, it is clear that research on this topic "is still in its infancy" (Lin et al., 2017, p. 732).

Over thirty years ago when learner-learner interaction was still a largely new "dimension of distance education" (p. 4), Moore (1989) predicted that it would "be a challenge to our thinking and practice" (p. 4). While learner-learner interactions are more prevalent in online courses, it seems as though learner-learner interactions remain a "challenge to our thinking and practice" (Moore, 1989, p. 4). The ACE framework proved helpful in guiding this research and identifying indicators of peer engagement. However, this and other research (Borup, 2016) found that the ACE framework did not capture an important indicator of peer engagement-developing relationships. Additionally, an important limitation of the ACE framework is that it largely focuses on the peer engagement that occurs within the course community. This is important limitation because earlier research found that students actually received more support from their in-person peers than their peers enrolled in their online course (Oviatt, Graham, Davies, \& Borup, 2018). Borup, Graham, West, Archambault, and Spring (2020) recently revised the ACE framework and renamed it the Academic Communities of Engagement framework in part to better describe how both a student's course community (e.g., teachers, peers, mentors who make up the course or program) and personal community (e.g., parents, friends, other individuals who support the student but are not officially members of the course or program) can support the student's engagement in online and blended courses (see Figure 1).

We call on researchers to build on our efforts to apply the Academic Communities of Engagement framework using a variety of research methods in a diversity of settings. While difficult, this coordinated research effort has the potential to improve learning outcomes and better prepare students for higher education and future employment. 


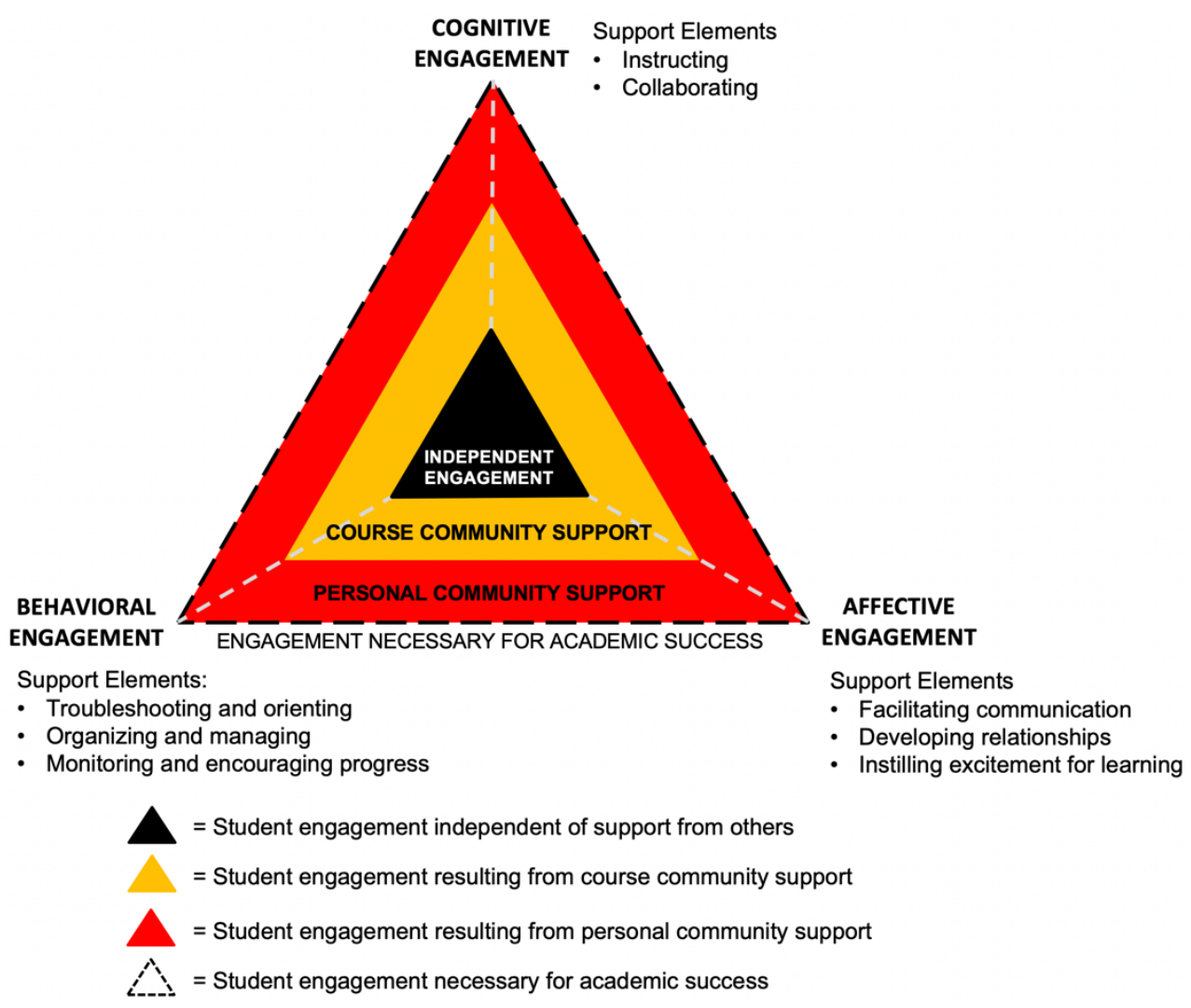

Figure 1. The area of the inner black triangle represents a student's ability to independently engage behaviorally, affectively, and cognitively in learning activities. In order to achieve academic success, as indicated by the outer dotted triangle, the student likely requires supports from those in the course community (e.g., teachers, peers, mentors) and personal community (e.g., parents, friends). The framework also aligns support elements with each type of engagement rather than specific support actor (Borup et al., 2020, p. 810). 


\section{References}

Anderson, T. (2009). A rose by any other name: Still distance education - a response to D . R . Garrison: "Implications of online and blended learning for the conceptual development and practice of distance education." Journal of Distance Education, 23(3), 111-116.

Anderson, T., Rourke, L., Garrison, D. R., \& Archer, W. (2001). Assessing teaching presence in a computer conferencing context. Journal of Asynchronous Learning Networks, 5(2), 1-17.

Archer, W. (2010). Beyond online discussions: Extending the community of inquiry framework to entire courses. The Internet and Higher Education, 13(1-2), 69. https://doi.org/10.1016/j.iheduc.2009.10.005

Borup, J., Graham, C. R., \& Davies, R. S. (2013). The nature of adolescent learner interaction in a virtual high school setting. Journal of Computer Assisted Learning, 29(2). https://doi.org/10.1111/j.1365-2729.2012.00479.x

Borup, J., Graham, C. R., West, R. E., Archambault, L., \& Spring, K. J. (2020). Academic communities of engagement: An expansive lens for examining support structures in blended and online learning. Educational Technology Research and Development. 68, 807-832. https://doi.org/10.1007/s11423-020-09744-X

Borup, J., West, R. E., Thomas, R. A., \& Graham, C. R. (2014). Examining the impact of video feedback on instructor social presence in blended courses. International Review of Research in Open and Distance Learning, 15(3).

Borup, J., West, R. E., Graham, C. R., \& Davies, R. S. (2014). The Adolescent Community of Engagement: A framework for research on adolescent online learning. Journal of Technology and Teacher Education, 22(1), 107-129.

Borup, J. (2016). Teacher perceptions of learner-learner engagement at a cyber high school. International Review of Research in Open and Distance Learning, 17(3). https://doi.org/10.19173/irrodl.v17i3.2361

Beck, D. E., Maranto, R., \& Lo, W.-J. (2013). Determinants of student and parent satisfaction at a cyber charter school. The Journal of Educational Research. https://doi.org/10.1080/00220671.2013.807494

Beck, D., Egalite, A., \& Maranto, R. (2014). Why they choose and how it goes: Comparing special education and general education cyber student perceptions. Computers \& Education, 76, 70-79. https://doi.org/10.1016/j.compedu.2014.03.011

Beldarrain, Y. (2008). Engaging the 21st century learner: An exploratory study of the relationship between interaction and achievement in the virtual high school [Doctoral dissertation, Capella University, Minnesota]. LearnTechLib. https://www.learntechlib.org/p/115817/

Carspecken, P. F. (1996). Critical ethnography in educational research: A theoretical and practical guide. Routledge.

Carver, D. L., \& Kosloski, M. F. (2015). Analysis of student perceptions of the psychosocial learning environment in online and face-to-face career and technical education courses. The Quarterly Review of Distance Education, 16(4), 7-21.

Dawley, L., Rice, K., \& Hinck, G. (2010). Going virtual! 2010: The status of professional development and unique needs of K-12 online teachers. Boise State University. https://aurorainstitute.org/wp-content/uploads/goingvirtual3.pdf 
Digital Learning Collaborative. (2019). Snapshot 2019: A review of K-12 online, blended, and digital learning. https://www.evergreenedgroup.com/s/DLC-KP-Snapshot2019.pdf

Garrett Dikkers, A. (2018). Social Interaction in K-12 Online Learning. In K. Kennedy and R. Ferdig (Eds.), Handbook of research on K-12 online and blended learning (2nd ed., pp. 509-522). ETC Press. http://repository.cmu.edu/etcpress/82/

Garrett Dikkers, A., Whiteside, A. L., \& Lewis, S. (2013). Virtual high school teacher and student reactions to the social presence model. Journal of Interactive Online Learning, 12(3), 156-170.

Garrison, D. R., Anderson, T., \& Archer, W. (2001). Critical thinking, cognitive presence, and computer conferencing in distance education. American Journal of Distance Education, 15(1), 7-23. https://doi.org/10.1080/08923640109527071

Garrison, D. R., Anderson, T., \& Archer, W. (2000). Critical inquiry in a text-based environment: Computer conferencing in higher education. The Internet and Higher Education, 2(2-3), 87105. https://doi.org/10.1016/S1096-7516(00)00016-6

Garrison, R. (2009). Implications of online learning for the conceptual development and practice of distance education. Journal of Distance Education, 23(2), 93-104.

Gemin, B., \& Pape, L. (2017). Keeping pace with K-12 online learning 2016. Evergreen Education Group. http://files.eric.ed.gov/fulltext/ED576762.pdf

Gill, B., Walsh, L., Wulsin, C. S., Matulewicz, H., Severn, V., Grau, E., ... Kerwin, T. (2015). Inside online charter schools. Walton Family Foundation and Mathematica Policy Research. http://www.mathematicampr.com/ /media/publications/pdfs/education/inside_online_charter_schools.pdf

Graham, C. R., Henrie, C. R., \& Gibbons, A. S. (2014). Developing models and theory for blended learning research. In A. G. Picciano, C. D. Dziuban, \& C. R. Graham (Eds.), Blended learning: Research perspectives, volume 2 (pp. 13-33). Taylor \& Francis.

Harvey, D., Greer, D., Basham, J., \& Hu, B. (2014). From the student perspective: Experiences of middle and high school students in online learning. American Journal of Distance Education, 28(1), 14-26. https://doi.org/10.1080/08923647.2014.868739

Lin, C., Zheng, B., \& Zhang, Y. (2017). Interactions and learning outcomes in online language courses. British Journal of Educational Technology, 48(3), 730-748. https://doi.org/10.1111/bjet.12457

Lincoln, Y. S., \& Guba, E. G. (1985). Naturalistic inquiry. Sage.

Merriam, S. B. (1998). Qualitative research and case study applications in education: Revised and expanded from case study research in education. Jossey-Bass.

Merriam, S. B., \& Tisdell, E. J. (2009). Qualitative research: A guide to design and implementation. John Wiley \& Sons.

Moore, M. G. (1989). Editorial: Three types of interaction. The American Journal of Distance Education, 3(2), 1-6.

National Education Association. (n.d.). Preparing 21st Century students for a global society: An educator's guide to the "Four Cs." http://www.nea.org/assets/docs/A-Guide-to-Four-Cs.pdf 
Oliver, K., Osborne, J., \& Brady, K. (2009). What are secondary students' expectations for teachers in virtual school environments? Distance Education, 30(1), 23-45.

https://doi.org/10.1080/01587910902845923

Oviatt, D. R., Graham, C. R., Davies, R. S., \& Borup, J. (2018). Online student use of a proximate community of engagement in an independent study program. Online Learning Journal, 22(1). https://doi.org/10.24059/olj.v22i1.1153

Patton, M. Q. (2002). Qualitative research and evaluation methods (3rd ed.). Sage.

Rourke, L., Anderson, T., Garrison, D. R., \& Archer, W. (2001). Assessing social presence in asynchronous text-based computer conferencing. Journal of Distance Education, 14(2), 51-70. http://www.jofde.ca/index.php/jde/article/view/153/341

Rice, K. (2012). Making the move to K-12 online teaching: Research-based strategies and practices. Pearson.

Short, J., Williams, E., \& Christie, B. (1976). The social psychology of telecommunications. John Wiley \& Sons.

Thomas, R. A., West, R. E., \& Borup, J. (2017). An analysis of instructor social presence in online text and asynchronous video feedback comments. The Internet and Higher Education, 33, 6173. https://doi.org/10.1016/j.iheduc.2017.01.003

Tysinger, D., Tysinger, J. A., \& Diamanduros, T. D. (2016). Crisis events in K-12 online learning: Educator perceptions and preparedness. National Youth-At-Risk Journal, 2(1). https://doi.org/10.20429/nyarj.2016.020104

Velasquez, A., Graham, C. R., \& West, R. E. (2013). An investigation of practices and tools that enabled technology-mediated caring in an online high school. The International Review of Research in Open and Distance Learning, 14(5), 277-299. http://www.irrodl.org/index.php/irrodl/article/view/1465/2758

Watson, J., Murin, A., Vashaw, L., Gemin, B., \& Rapp, C. (2014). Keeping pace with K-12 online learning: An annual review of policy and practice. Evergreen Education Group. https://static1.squarespace.com/static/59381b9a17bffc68bf625df4/t/5949b5ad1b631b5c53e1fdd d/1498002869656/KeepingPace+2010.pdf

Wolcott, H. F. (1994). Transformative qualitative data: Description, analysis, and interpretation. Sage.

Zhang, Y., Liu, H., and Lin, C. H. (2018) Research on class size in K-12 online learning. In K. Kennedy and R. Ferdig (Eds.), Handbook of research on K-12 online and blended learning (2nd ed., pp. 423-442). ETC Press. http://repository.cmu.edu/etcpress/82/

Zeneli, M., Thurston, A., \& Roseth, C. (2016). The influence of experimental design on the magnitude of the effect size -peer tutoring for elementary, middle and high school settings: A meta-analysis. International Journal of Educational Research, 76, 211-223. https://doi.org/10.1016/j.ijer.2015.11.010 